JURNAL ILMU KESEHATAN BHAKTI HUSADA:

HeAlth SCIENCES Journal, Vol. 11 No. 02, DeSEMBER 2020

DOI: $10.34305 / j i k b h . v 11$ i2.205
Ciptaan disebarluaskan di bawah

Lisensi Creative Commons

Atribusi-NonKomersial-

BerbagiSerupa 4.0 Internasional.

\title{
PENGEMBANGAN MODEL BLENDED LEARNING DALAM MENINGKATKAN LEARNING OUTCOME MAHASISWA DI LAHAN PRAKTIK KLINIK KEPERAWATAN
}

\author{
Hendi Rohendi, Ujeng, Lia Mulyati \\ STIKes Kuningan \\ lia@pintarword.com
}

\begin{abstract}
Abstrak
Praktik klinik keperawatan merupakan elemen penting bagi pendidikan keperawatan. Penempatan yang berkualitas memberi kesempatan kepada mahasiswa untuk pengembangan keterampilan, sosialisasi ke dalam profesi, dan menjadi jembatan antara pembelajaran akademik dan tempat kerja. Pada kondisi pandemic ini seluruh mahasiswa tidak diperkenankan untuk melakukan praktik klinik keperawatan di rumah sakit untuk mengurangi risiko keterpaparan Covid 19, oleh karena itu pembelajaran dilakukan secara online dan offline di tatanan kampus. Penelitian ini bertujuan mengembangkan dan menganalisis efektivitas model blended learning dalam praktik klinik keperawatan terhadap peningkatan learning outcome dan tingkat kepuasan mahasiswa program profesi Ners STIKes Kuningan pada departemen Keperawatan Medikal Bedah, dengan membandingkan metode pembelajaran Blended Klinik-Daring dengan metode PBL-Daring serta membandingkan capaian mahasiswa regular dan non regular. Capaian learning outcome dikategorikan tinggi, sedang dan rendah. Jenis penelitian yang digunakan adalah quasi eksperimen dengan pre dan post test. Sampel penelitian ini adalah mahasiswa program profesi ners yang sedang melakukan praktik klinik keperawatan medikal bedah, sejumlah 60 orang. Two way anova dan post hoc test digunakan sebagai analisis lanjutan. Berdasarkan hasil analisis tes metode belajar Blended Preseptorship-Daring lebih efektif dalam pencapaian learning outcome keperawatan medikal bedah dengan N-G score 0.50 dibandingkan dengan pembelajaran Blended PBL-Daring dengan nilai F 5.36 dan nilai p $0.001<0.05$ yang menunjukan adanya hubungan yang signifikan antara pembelajaran di kelas mahasiswa reguler dan nonreguler dengan pembelajaran Blended Preseptor-Daring dan PBL-Daring, dan memiliki kekuatan hubungan sangat kuat R 0.822. Hasil kuesioner juga ditemukan tingkat kepuasan mahasiswa dengan pembelajaran blended learning baik dengan PBL maupun klinik merasa puas dan metode ini dapat menjadi solusi selama pembelajaran program profesi Ners di masa pandemi.
\end{abstract}

Kata kunci; Blended learning, problem based learning, praktik klinik. 
JURNAL ILMU KESEHATAN BHAKTI HUSADA:

HeAlth SCIENCES Journal, Vol. 11 No. 02, Desember 2020

DOI: $10.34305 / j i k b h . v 11 \mathrm{i} 2.205$

\section{Pendahuluan}

Praktik klinik keperawatan merupakan elemen penting bagi pendidikan keperawatan, pada masa tersebut mahasiswa dapat mengaplikasikan berbagai macam teori keperawatan, dan keterampilan. Selain itu, mahasiswa mendapatkan nilai-nilai profesionalisme seorang perawat selama mereka berinteraksi baik dengan pasien, perawat ruangan, tim kesehatan lain maupun pembimbing klinik, dengan demikian keberhasilan pembelajaran di lingkungan klinik sangat menunjang capaian learning outcome dan profil perawat yang diharapkan.

Lingkungan klinis dapat berupa lingkungan rumah sakit, masyarakat, puskesmas dan layanan kesehatan untuk komunitas tertentu. Penempatan yang berkualitas memberi kesempatan kepada mahasiswa untuk pengembangan keterampilan, sosialisasi ke dalam profesi, dan menjadi jembatan antara pembelajaran akademik dan tempat kerja. Hubungan antara staf dan mahasiswa keperawatan adalah faktor krusial dalam menciptakan lingkungan belajar yang positif (CNA, 2004)

Metode preseptorship adalah salah satu metode yang saat ini banyak
Ciptaan disebarluaskan di bawah

Lisensi Creative Commons

Atribusi-NonKomersial-

BerbagiSerupa 4.0 Internasional.

diterapkan untuk meningkatkan kualitas pembelajaran di area klinik. Menurut CNA (2004) program preseptorship dalam pembelajaran bertujuan untuk membentuk peran dan tanggung jawab mahasiswa untuk menjadi perawat profesional dan berpengetahuan tinggi. Metode ini terbukti efektif dalam meningkatkan kompetensi perawat, namun demikian tidak mudah diterapkan.

Terdapat beberapa kendala yang dihadapi, berdasarkan studi pendahuluan yang dilakukan terhadap mahasiswa program studi Ners STIKes Kuningan ditemukan beberapa fakta; 1 . sebagian besar mahasiswa merasakan kurang memiliki waktu untuk mendapatkan kompetensi karena sebagian besar waktu digunakan untuk melakukan kegiatan rutinitas di ruangan 2. Belum adanya kesamaan persepsi antara pembimbing klinik dengan pembimbing akademik untuk capaian learning outcome mahasiswa, 3. $62 \%$ mahasiswa kurang paham target/learning outcome yang harus dicapai selama pembelajaran di klinik, 4. 47,4\% mahasiswa mengatakan bahwa bimbingan klinik yang dilakukan oleh pembimbing klinik masih kurang. 
JURNAL ILMU KESEHATAN BHAKTI HUSADA:

HeAlth SCIENCES Journal, Vol. 11 No. 02, Desember 2020

DOI: $10.34305 / j i k b h . v 11 \mathrm{i} 2.205$

Permasalahan ini didukung oleh beberapa kondisi diantaranya; 1. Perbandingan jumlah mahasiswa dengan pembimbing klinik yang tidak sebanding, 2. Job description pembimbing klinik tumpang tindih dengan tugas utama 3. Frekuensi bimbingan pembimbing akademik sangat terbatas karena ada keterbatasan waktu dan jarak. Hal ini berdampak pada rendahnya capaian learning outcome khususnya departemen keperawatan medikal bedah ketercapaian learning outcome 51,7\% hal tersebut tentunya masih jauh dari harapan.

Blended learning dirancang dengan mencampurkan beberapa metode belajar yang dikemas sedemikian rupa sehingga bisa memfasilitasi capaian mahasiswa sesuai dengan kebutuhan. Sebagai upaya mengoptimalkan capaian tujuan pembelajaran di lahan praktek klinik khususnya di masa pandemik, Blended learning merupakan solusi pembelajaran karena metode ini memberikan kesempatan untuk mengintegrasikan antara inovasi dan teknologi yang diberikan dalam bentuk online learning. Menurut Staker \& Horn (2012), blended learning merupakan sebuah program pendidikan formal di mana seorang mahasiswa belajar melalui penyampaian
Ciptaan disebarluaskan di bawah

Lisensi Creative Commons

Atribusi-NonKomersial-

BerbagiSerupa 4.0 Internasional.

konten dan instruksi online.

Banyak penelitian yang membuktikan bahwa metode preseptorship efektif meningkatkan kompetensi perawat, seperti penelitian yang dilakukan oleh Sulung \& neila (2016), yang menunjukan bahwa metode preceptor- mentor dapat meningkatkan kompetensi perawat anak dilihat dari nilai rata-rata: motivasi internal, kemampuan manajemen, motivasi ekstrinsik, kompetensi perawat dan mutu pelayanan. Begitupun penelitian yang dilakukan oleh Tursina et al. (2016), menunjukan bahwa bimbingan preceptorship model kognitif sosial mempunyai pengaruh terhadap peningkatan kompetensi klinis mahasiswa.

Berbeda dengan penelitian yang dilakukan di Amerika mengenai perbandingan antara metode pembelajaran konvensional dan preceptorship. Didapatkan hasil bahwa tidak terdapat perbedaan yang signifikan antara kelompok preceptorship dan kelompok konvensional terhadap pengetahuan, begitupun dengan tingkat capaian kemampuan keterampilan (Alfi, 2017)

Penelitian yang dilakukan oleh Omer (2013), dalam jurnal yang berjudul 
JURNAL ILMU KESEHATAN BHAKTI HUSADA:

HeAlth SCIENCES Journal, Vol. 11 No. 02, Desember 2020

DOI: $10.34305 /$ jikbh.v11i2.205

"Perception of nursing students to two models of preceptorship in clinical training" yang melihat perbedaan antara dua model preceptorship, model A yaitu preceptorship yang memerlukan bimbingan intensif dengan model B yaitu preceptorship yang lebih menekankan pada kemandirian peserta didik dalam belajar. Hasil yang diperoleh dari penelitian tersebut adalah pada setiap variabel yang diteliti mulai dari kepuasan preceptee, pendukung program, penampilan preceptor (sebagai guru, fasilitator, role model, pemberi umpan balik, mahir dalam pembelajaran orang dewasa dan advokat) secara signifikan lebih mendukung model A.

Menurut Suryani \& Agung (2017), lingkungan belajar klinik perlu disiapkan dengan baik untuk memenuhi kebutuhan dan meningkatkan motivasi belajar mahasiswa. Hasil penelitiannya menyimpulkan bahwa komponen penting dalam pembelajaran klinik adalah peran pembimbing yang mendorong terwujudnya kualitas pelayanan dan pembelajaran klinik, kesiapan mahasiswa sebelum memasuki tahap pendidikan klinik dan pengalaman belajar klinik yang sesuai dengan kebutuhan mahasiswa. Lingkungan klinik merupakan
Ciptaan disebarluaskan di bawah

Lisensi Creative Commons

Atribusi-NonKomersial-

BerbagiSerupa 4.0 Internasional.

wadah bagi peserta didik untuk belajar pemeriksaan fisik, argumentasi klinik, pengambilan keputusan, empati, serta profesionalisme yang diajarkan dan dipelajari sebagai satu kesatuan.

Menurut Staker \& Horn (2012), blended learning merupakan sebuah program pendidikan formal di mana seorang mahasiswa belajar melalui penyampaian konten dan instruksi online dengan beberapa elemen kontrol terhadap mahasiswa ditinjau dari waktu, tempat, jalur, atau langkahlangkah dan pengawasan yang dilakukan secara jarak jauh. Metode pembelajaran Blended learning dikemas dalam bentuk; 1 . Teknologi multimedia, 2. CD room video streaming, 3. Virtual class room, 4. Voice mail, email dan conference calls, 5. Online text, animasi dan video streaming (aplikasi Zoom).

Blended learning memberikan fasilitas belajar yang sangat sensitif terhadap segala perbedaan waktu, jarak dan karakteristik psikologis maupun lingkungan belajar. Hal ini representatif untuk diaplikasikan kepada peserta didik yang terkendala dalam jarak dan waktu.

Salah satu model blended learning adalah Flipped-Problem Based Learning 
JURNAL ILMU KESEHATAN BHAKTI HUSADA:

HeAlth SCIENCES Journal, Vol. 11 No. 02, DeSEMBer 2020

DOI: $10.34305 /$ jikbh.v1112.205
Ciptaan disebarluaskan di bawah

Lisensi Creative Commons

Atribusi-NonKomersial-

BerbagiSerupa 4.0 Internasional.

yang diintegrasikan dengan media digital

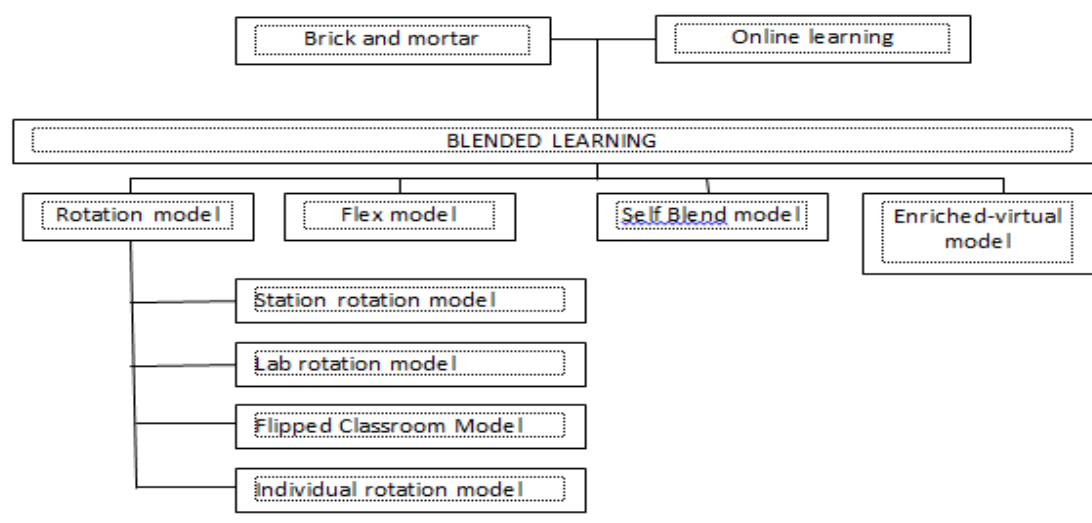

Gambar 1. Tipe model Blended learning (Staker \& Horn, 2012)

Model Flipped-problem based learning

menggunakan dua fase pembelajaran, fase pertama pembelajaran tatap muka dan fase

kedua pembelajaran di luar tatap muka atau dengan menggunakan digital learning.
Langkah langkah kegiatan pembelajaran mengacu pada pembelajaran berbasis masalah/ problem based learning yang meliputi; orientasi, organisasi, investigasi, analisis dan evaluasi (Rahmi et al., 2019).

\section{Tabel 1. Syntax Model Flipped Problem Based Learning}

\begin{tabular}{|c|c|c|}
\hline Langkah & Prosedur & Kegiatan Mahasiswa \\
\hline 1 & $\begin{array}{l}\text { Orientasi } \\
\text { masalah }\end{array}$ & $\begin{array}{l}\text { Mahasiswa memahami detail masalah yang akan dibahas. Soal diambil dari bahan } \\
\text { ajar yang dipelajari. }\end{array}$ \\
\hline 2 & $\begin{array}{l}\text { Mahasiswa } \\
\text { Terorganisir }\end{array}$ & $\begin{array}{l}\text { Mahasiswa menganalisis dan mencari tahu bagaimana menyelesaikan masalah. } \\
\text { Mahasiswa dapat menyelesaikan masalah dengan mencari masalah yang mirip atau } \\
\text { mirip dengan masalah yang dianalisis. Pada tahap ini mahasiswa dapat } \\
\text { mengelompokkan rincian masalah yang dibahas. }\end{array}$ \\
\hline 3 & $\begin{array}{l}\text { Panduan } \\
\text { Investigasi } \\
\text { sebagai Individu } \\
\text { atau Grup }\end{array}$ & $\begin{array}{l}\text { Setelah mahasiswa mengklasifikasikan rincian masalah yang akan dibahas, } \\
\text { mahasiswa dapat menyelidiki masalah tersebut secara individu maupun kelompok. }\end{array}$ \\
\hline 4 & $\begin{array}{l}\text { Pengembangan } \\
\text { dan Presentasi } \\
\text { Pencapaian }\end{array}$ & $\begin{array}{l}\text { Mahasiswa dapat mengembangkan dan mempresentasikan hasil pembahasan dari } \\
\text { masalah yang sedang dibahas. Pada tahap ini mahasiswa dapat membandingkan } \\
\text { langkah-langkah untuk menyelesaikan masalah lainnya dan mengetahui langkah- } \\
\text { langkah untuk menyelesaikan masalah yang paling tepat. }\end{array}$ \\
\hline 5 & $\begin{array}{l}\text { Analisis dan } \\
\text { Evaluasi } \\
\text { Pemecahan } \\
\text { Masalah }\end{array}$ & $\begin{array}{l}\text { Mahasiswa dapat melakukan analisis untuk merefleksikan dan mengevaluasi hasil } \\
\text { investigasi mengenai pemecahan masalah yang sedang dibahas. Mahasiswa dapat } \\
\text { menyimpulkan pemecahan masalah yang benar dan tepat. }\end{array}$ \\
\hline
\end{tabular}


JURNAL ILMU KESEHATAN BHAKTI HUSADA:

HeAlth SCIENCES Journal, Vol. 11 No. 02, DeSEMBER 2020

DOI: $10.34305 /$ jikbh.v11i2.205

\section{METODE PENELITIAN}

Penelitian ini merupakan kuasi eksperimen dengan kontrol. Penelitian ini membandingkan hasil pembelajaran antara mahasiswa reguler dan mahasiswa non
Ciptaan disebarluaskan di bawah

Lisensi Creative Commons

Atribusi-NonKomersial-

BerbagiSerupa 4.0 Internasional.

reguler/ memiliki pengalaman kerja yang diberikan pembelajaran dengan metode campuran. Alur penelitian dijelaskan pada gambar 2.

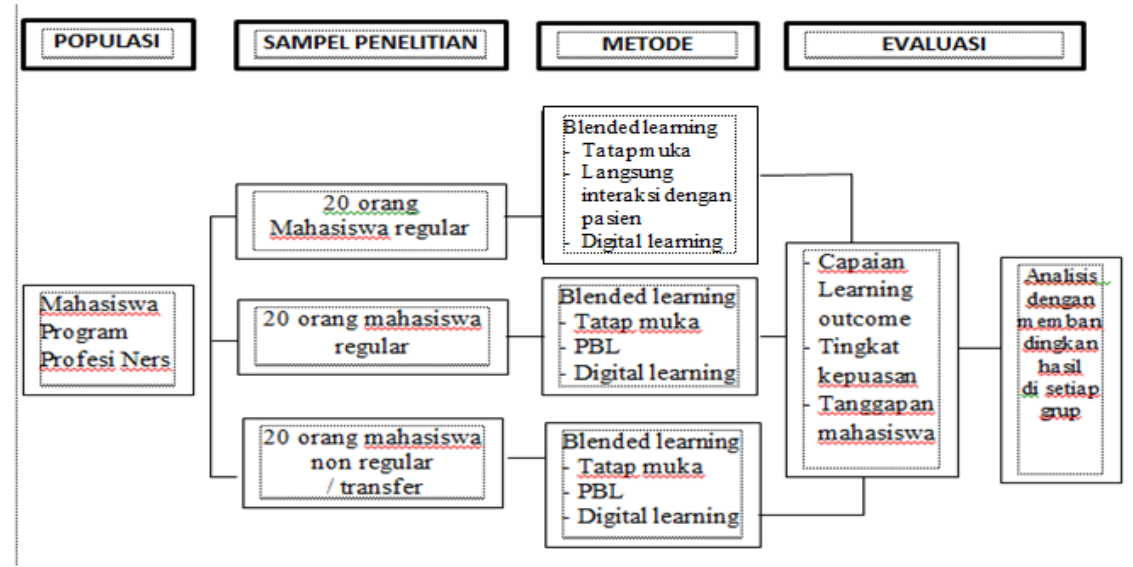

Gambar 2. Alur penelitian

\section{Sampel penelitian}

Jumlah mahasiswa yang mengikuti program profesi Ners tahun akademik 2018/2019 di departemen keperawatan medikal bedah sebanyak 60 yang terdiri dari 20 mahasiswa reguler yang mengikuti pembelajaran klasikal di lahan praktik, 20 mahasiswa reguler dan 20 mahasiswa transfer (non reguler) yang mengikuti pembelajaran dengan metode blended learning. Penelitian dilakukan selama masa pendidikan program profesi Ners selama 7 minggu.

\section{Instrumen penelitian}

Instrumen yang digunakan dalam penelitian ini adalah kuesioner. Terdapat empat kuesioner; tiga kuesioner digunakan untuk menilai kemampuan/perkembangan mahasiswa yaitu; kuesioner tentang tanggapan mahasiswa terhadap pembelajaran blended learning, ketercapaian learning outcome, dan tingkat kepuasan mahasiswa terhadap penerapan blended 
JURNAL ILMU KESEHATAN BHAKTI HUSADA:

HeAlth SCIENCES Journal, Vol. 11 No. 02, DeSEMBER 2020

DOI: $10.34305 /$ jikbh.v11i2.205

learning di area klinik.

\section{Hasil}

Penelitian ini merupakan kuasi eksperimen. Penelitian ini membandingkan hasil pembelajaran antara mahasiswa reguler dan mahasiswa non reguler/memiliki pengalaman kerja yang diberikan
Ciptaan disebarluaskan di bawah

Lisensi Creative Commons

Atribusi-NonKomersial-

BerbagiSerupa 4.0 Internasional.

pembelajaran dengan metode blended learning. Analisis data penelitian dilakukan dengan deskriptif menggunakan tendensi sentral; mean, median dan standar deviasi dan untuk analisis lanjutan menggunakan inferential two-way Anova test dengan post hoc test.

TABEL 2. Deskripsi learning outcome mahasiswa reguler dengan pembelajaran Preseptorship-daring, regular pembelajaran PBL-daring, Non regular PBLDaring.

\begin{tabular}{lllcccc}
\hline & Kelompok & N & Mean & Std Deviasi & Minimum & Maksimum \\
\hline Reguler Preseptorship-Daring & Pretest & 20 & 42.85 & 12.5 & 20 & 70 \\
& Post test & 20 & 72.35 & 10.3 & 47 & 87 \\
\multirow{2}{*}{ Reguler PBL-Daring } & Pretest & 20 & 49.25 & 15.47 & 17 & 77 \\
\multirow{2}{*}{ Non Reguler-PBL-Daring } & Post test & 20 & 61.30 & 14.13 & 33 & 100 \\
& Pretest & 20 & 43.15 & 14.1 & 20 & 80 \\
& Post test & 20 & 69.5 & 14.47 & 43 & 100 \\
\hline
\end{tabular}

Berdasarkan data tersebut Kelompok mahasiswa dengan pembelajaran preseptorship-daring mendapatkan rata rata post test paling tinggi. Untuk mengetahui efektifitas dari satu perlakuan dilakukan dengan cara menghitung Normalize Gain atau N-G score. Hasil peningkatan belajar mahasiswa pada tiga kelompok penelitian dijelaskan pada tabel 2.

Tabel 3. N-Gain Learning outcome Keperawatan Medikal Bedah pada kelas reguler klinik-daring, regular PBL- daring, dan non reguler PBL-daring

\begin{tabular}{ccccccc}
\hline & N & Minimum & Maksimum & Mean & Standar Deviasi & Varians \\
\hline Regular Preseptor-daring & 20 & 0.19 & 0.81 & 0.50 & 0.17 & 0.31 \\
Reguler PBL-daring & 20 & 0.00 & 1 & 0.23 & 0.22 & 0.50 \\
NonReguler PBL-Daring & 20 & -0.4 & 1 & 0.41 & 0.34 & 0.11 \\
\hline
\end{tabular}

Berdasarkan Tabel 2 di atas terlihat bahwa learning outcome mahasiswa kelas 
JURNAL ILMU KESEHATAN BHAKTI HUSADA:

HeAlth SCIENCES Journal, Vol. 11 No. 02, DeSEMBER 2020

DOI: $10.34305 /$ jikbh.v11i2.205

reguler dengan pembelajaran Klinik-Daring didapatkan rerata $\mathrm{N}$-Gain 0.50 (dengan kategori sedang), mahasiswa kelas reguler dengan pembelajaran PBL-Daring didapatkan rerata $\mathrm{N}$-Gain 0.23 (kategori rendah), sementara untuk kelompok mahasiswa non reguler dengan pembelajaran PBL-Daring diperoleh rerata N-Gain 0.34 (kategori sedang). Tampak terdapat perbedaan antara kelas reguler metode Blended Klinik-Daring dan Kelas mahasiswa non reguler metode PBL-Daring dengan kelas reguler metode PBL-Daring.
Ciptaan disebarluaskan di bawah

Lisensi Creative Commons Atribusi-NonKomersial-

BerbagiSerupa 4.0 Internasional.

Perhitungan normalitas data hasil belajar dilakukan dengan menggunakan Tes Kolmogorov-Smirnov, dengan hasil pengujian diperoleh hasil $0.133>0,05$, sehingga dapat disimpulkan data tersebut berdistribusi normal. Untuk melihat homogenitas dilakukan perhitungan dengan menggunakan tes Levene dengan nilai $p$ 0.079, berdasarkan data tersebut maka data dinyatakan homogen sehingga analisis lanjutan dengan menggunakan two way anova dan post hoc test dapat dilakukan.

Tabel 4. Hasil analisis two way ANOVA

\begin{tabular}{lcccc}
\hline \multicolumn{1}{c}{ Source } & df & Mean Square & F & Sig \\
\hline Corrected model & 8 & 4583.18 & 29.41 & .000 \\
Intercept & 1 & 77496.55 & 497.31 & .000 \\
Kelas & 2 & 18.37 & 0.12 & .889 \\
Learning outcome & 2 & 12444.67 & 79.86 & .000 \\
Kelas*Learning Outcome & 4 & 835.82 & 5.36 & .001 \\
\hline Total & 60 & & & \\
\hline
\end{tabular}

a. $\quad$ R Squared $=.822($ Adjusted R Squared $=.794)$

Berdasarkan Tabel 3 di atas didapatkan nilai corrected model $0.000<$ 0.05 artinya model yang digunakan sudah tepat, dan di dapatkan nilai F 5.36 dengan nilai $\mathrm{p} 0.001<0.05$ yang menunjukan adanya hubungan yang signifikan antara pembelajaran di kelas mahasiswa reguler dan nonreguler dengan pembelajaran Blended Preseptor-Daring dan PBL-Daring, dengan nilai $\mathrm{R} \quad 0.822$ artinya terdapat hubungan yang sangat kuat. 
JURNAL ILMU KESEHATAN BHAKTI HUSADA:

HeAlTh SCIENCES Journal, Vol. 11 No. 02, DeSEMBER 2020

DOI: $10.34305 /$ jikbh.v11i2.205
Ciptaan disebarluaskan di bawah

Lisensi Creative Commons

Atribusi-NonKomersial-

BerbagiSerupa 4.0 Internasional.

Tabel 5. Tingkat Kepuasan Mahasiswa Tentang Penerapan Metode Blended Learning Dalam Pembelajaran Klinik Program Profesi Ners

\begin{tabular}{|c|c|c|c|c|c|c|c|c|c|c|c|c|c|c|c|c|}
\hline \multirow[t]{2}{*}{ NO } & \multirow[t]{2}{*}{ Pernyataan } & \multicolumn{3}{|c|}{$\begin{array}{l}\text { Sangat } \\
\text { setuju } \\
(\%)\end{array}$} & \multicolumn{3}{|c|}{$\begin{array}{c}\text { Setuju } \\
(\%)\end{array}$} & \multicolumn{3}{|c|}{$\begin{array}{c}\text { Ragu-ragu } \\
(\%)\end{array}$} & \multicolumn{3}{|c|}{$\begin{array}{l}\text { Tidak } \\
\text { setuju } \\
(\%)\end{array}$} & \multicolumn{3}{|c|}{$\begin{array}{c}\text { Sangat } \\
\text { tidak } \\
\text { setuju } \\
(\%) \\
\end{array}$} \\
\hline & & A & B & $\mathrm{C}$ & A & B & $\mathrm{C}$ & A & B & C & A & B & C & $\mathrm{A}$ & B & $\mathrm{C}$ \\
\hline 1 & $\begin{array}{l}\text { e-learning membantu saya } \\
\text { meningkatkan pemahaman saya } \\
\text { untuk materi keperawatan }\end{array}$ & 5 & 10 & 5 & 45 & 60 & 45 & 25 & 15 & 25 & 25 & 15 & 5 & 0 & 0 & 0 \\
\hline 2 & $\begin{array}{l}\text { e-learning membantu saya } \\
\text { meningkatkan pemahaman saya } \\
\text { tentang berbagai } \\
\text { keterampilan sesuai } \\
\text { SOP }\end{array}$ & 5 & 5 & 5 & 30 & 10 & 30 & 40 & 40 & 40 & 25 & 45 & 25 & 0 & 0 & 0 \\
\hline 3 & $\begin{array}{l}\text { e-learning membantu saya } \\
\text { meningkatkan pemahaman saya } \\
\text { dalam menganalisis masalah } \\
\text { keperawatan yang dihadapi oleh } \\
\text { pasien }\end{array}$ & 5 & 5 & 5 & 30 & 50 & 30 & 25 & 30 & 25 & 40 & 15 & 40 & 0 & 0 & 0 \\
\hline
\end{tabular}

\section{Grafik 1. Tanggapan Mahasiswa Tentang Penerapan Metode Blended Learning Dalam Pembelajaran Klinik Program Profesi Ners}

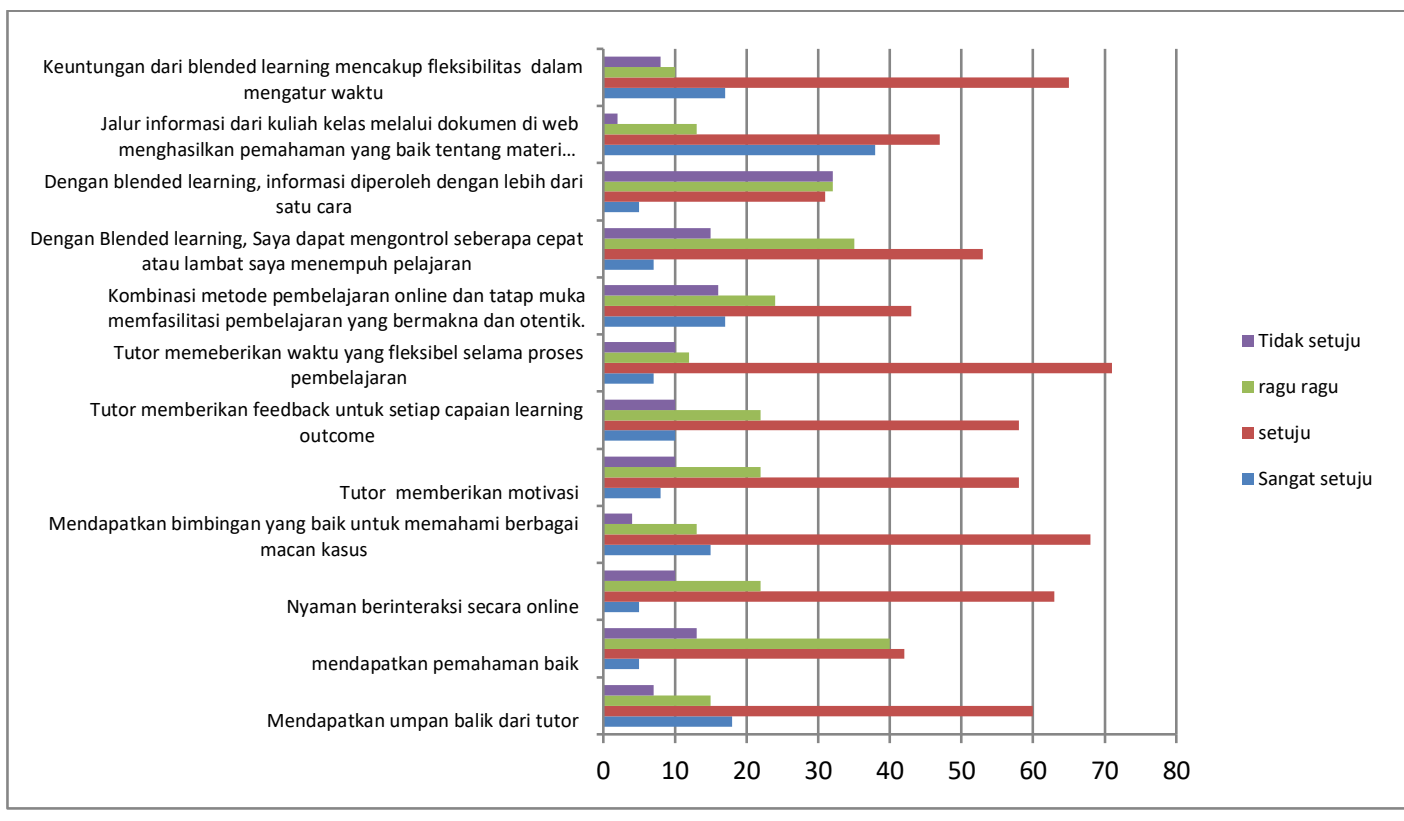

Berdasarkan tabel 4, persepsi mahasiswa

tentang e-learning sudah mampu meningkatkan kemampuan dari segi 
JURNAL ILMU KESEHATAN BHAKTI HUSADA:

HeAlth SCIENCES Journal, Vol. 11 No. 02, Desember 2020

DOI: $10.34305 /$ jikbh.v11i2.205

pengetahuan dan analisis namun dirasa kurang efektif dalam mencapai kemampuan psikomotor. Pada grafik 1 dapat digambarkan bahwa sebagian besar mahasiswa menilai bahwa tutor sudah dapat memfasilitasi proses pembelajaran dengan baik sehingga mereka dapat memahami materi yang disampaikan, mahasiswa merasa nyaman dan lebih leluasa dalam pengaturan jadwal belajar.

\section{Pembahasan}

Pembelajaran merupakan proses yang sangat penting dalam penyelenggaraan pendidikan, hal ini berarti keberhasilan pencapaian tujuan pendidikan sangat tergantung pada keberhasilan proses belajar mahasiswa di kampus dan lingkungan. Pada dasarnya pembelajaran merupakan tahapan perubahan perilaku mahasiswa yang relatif positif dan meningkatkan kemampuan sebagai hasil interaksi dengan lingkungan yang melibatkan proses kognitif (Jihad \& Abdul, 2012). Proses pembelajaran juga dapat membentuk service learning, yang terdiri dari komponen pengalaman belajar lapangan intrakurikuler yang terstruktur, refleksi, reciprocity (manfaat timbal balik), dan penentuan hasil dan manfaat yang
Ciptaan disebarluaskan di bawah

Lisensi Creative Commons

Atribusi-NonKomersial-

BerbagiSerupa 4.0 Internasional.

spesifik untuk semua pihak yang terlibat (Juniarti et al., 2016). Oleh karena itu, memilih model / metode pembelajaran yang tepat sangat menentukan learning outcomes yang akan dicapai oleh mahasiswa.

Pembelajaran klinik memberikan kesempatan kepada mahasiswa untuk menerapkan teori ke dalam keterampilan psikomotor secara langsung. Sehingga pembelajaran klinik dapat meningkatkan kompetensi atau perpaduan dari pengetahuan, keterampilan, nilai dan sikap yang direfleksikan dalam kebiasaan berpikir dan bertindak (Suhartanti, 2017). Hasilnya, mahasiswa mampu melakukan refleksi bagaimana kondisi pasien walaupun dilakukan secara daring. Selain itu, selama pembelajaran klinik mahasiswa mendapat bimbingan dari mentor dan preseptor, yang mana hal ini menurut Block et al., (2005), bahwa prinsip preceptor dan mentorship merupakan suatu cara yang terbaik untuk meningkatkan keterampilan perawat. Menurut Ferguson (2010), adanya persepsi yang sama antara mentor dan mentee dapat membuat perawat baru atau mahasiswa mau meniru. Stimulus seperti ini, dapat meningkatkan motivasi mahasiswa dalam belajar dan meningkatkan daya ingat 
JURNAL ILMU KESEHATAN BHAKTI HUSADA:

HeAlth SCIENCES Journal, Vol. 11 No. 02, Desember 2020

DOI: $10.34305 / j i k b h . v 11 \mathrm{i} 2.205$

mahasiswa karena berpraktik secara langsung. Prinsip ini sesuai dengan teori belajar aliran kognitif yang lebih mementingkan proses belajar dari pada hasil belajar itu sendiri. Belajar tidak hanya melibatkan hubungan antara stimulus dan respon, namun melibatkan proses berpikir yang lebih kompleks. Menurut teori ini ilmu pengetahuan dibangun dalam diri seorang individu melalui proses interaksi yang berkesinambungan dengan lingkungan (Kushartanti, 2007).

Kolaborasi metode blended learning dengan pembelajaran klinik memberikan hasil post test lebih tinggi dibanding dengan metode lainnya. Metode pembelajaran klinik memberikan kesempatan kepada mahasiswa untuk menerapkan teori ke dalam keterampilan psikomotor secara langsung. Sehingga pembelajaran klinik dapat meningkatkan kompetensi atau perpaduan dari pengetahuan, keterampilan, nilai dan sikap yang direfleksikan dalam kebiasaan berpikir dan bertindak (Suhartanti, 2017).

Berdasarkan hasil analisis skor ujian pre dan post test ditemukan bahwa rata rata hasil belajar pada kelas reguler dengan pembelajaran blended Preseptorship-Daring lebih tinggi dibandingkan dengan
Ciptaan disebarluaskan di bawah

Lisensi Creative Commons

Atribusi-NonKomersial-

BerbagiSerupa 4.0 Internasional.

pembelajaran PBL-Daring. Hasil analisis lainnya menunjukan bahwa pembelajaran dengan metode Blended preceptorshipdaring memberikan pengaruh yang signifikan terhadap capaian pembelajaran mahasiswa program profesi Ners untuk mata kuliah Keperawatan Medikal Bedah.

Pembelajaran berbasis masalah dan dipadukan dengan blended learning merupakan suatu terobosan dalam mendesain pembelajaran yang inovatif dalam hal penguasaan teknologi dan rendahnya kemampuan memecahkan masalah. Pembelajaran ini mendorong peserta didik dapat melakukan pemecahan masalah dan dapat dilaksanakan dalam kelas konvensional dan kelas virtual sehingga sesuai diterapkan pada era kekinian (Alfi, 2017). Mahasiswa memiliki peran menjadi objek dalam pembelajaran. Penelitian pengembangan model PBL berbasis blended learning mengharuskan mahasiswa untuk aktif dalam menggali, mencari, dan mengolah data, berpikir, berkomunikasi, dan di akhir tahap dapat menyimpulkan guna mendapatkan solusi atau pemecahan masalah atas permasalahan yang terjadi di lingkungan sekitarnya dengan cara yg efektif dan efisien dimana 
JURNAL ILMU KESEHATAN BHAKTI HUSADA:

HeAlth SCIENCES Journal, Vol. 11 No. 02, DeSEMBER 2020

DOI: $10.34305 /$ jikbh.v11i2.205

mahasiswa tidak perlu bertatap muka dalam pembelajarannya. Menurut Siahaan (2003), pembelajaran online pada blended learning dimungkinkan dapat mengembangkan fleksibilitas belajar yang tinggi. Hal tersebut senada dengan pendapat dari Waryanto (2006), bahwa mahasiswa dapat mengakses materi-materi pembelajaran dan dapat berkomunikasi dengan teman ataupun dosen setiap waktu sehingga mahasiswa akan lebih memantapkan penguasaan materi pembelajaran. Kegiatan pembelajaran berbasis masalah dengan blended learning melibatkan kreatifitas penuh. Kreatifitas tersebut berupa kegiatan mengamati lingkungan sekitar, menemukan konsep yang tepat guna proses pemecahan masalah serta melatih kemampuan bekerjasama dalam bekerja kelompok. Tahapan tersebut membentuk keterampilan bernalar dengan baik karena secara mandiri siswa memutuskan penemuan masalah dan solusinya. Artinya, siswa mengetahui kebutuhan belajarnya sendiri (Alfi, 2017).

Berdasarkan hasil penelitian metode pembelajaran blended learning dengan Problem-Based Learning (PBL), mendapatkan nilai post lebih rendah dibanding metode preseptorship-daring.
Ciptaan disebarluaskan di bawah

Lisensi Creative Commons Atribusi-NonKomersial-

BerbagiSerupa 4.0 Internasional.

Metode PBL sebetulnya dianggap sebagai metode yang efektif memfasilitasi pencapaian kompetensi perawat. Metode ini akan memberikan pengalaman bagi mahasiswa untuk menghadapi real-world problem solving. Namun, kegiatan yang berupa menyelesaikan masalah yang diberikan dalam bentuk kasus dengan menjelajahi konsep yang mereka kuasai, baik dengan meminta atau berdebat melalui diskusi selama kegiatan tutorial memerlukan waktu yang lebih lama, serta penugasan yang terasa berlebihan. Mahasiswa juga mengeluh peran yang tidak seimbang antara mahasiswa aktif dan tidak aktif, sistem pembelajaran monoton, kesulitan dan malas mencari literatur, jadwal ketat kuliah, dan perbedaan persepsi antara Penceramah (Erol et al., 2008). Literatur juga menunjukkan mahasiswa merasa frustasi saat menjalankan metode ini (Nurhidayah, 2017). Faktor lain yang dapat menghambat pembelajaran metode ini adalah belum siapnya akses internet yang dimiliki oleh mahasiswa. Hal ini tentunya bisa menghambat proses pembelajaran yang mengakibatkan kurang tercapainya target pembelajaran yang direncanakan. Peran akses internet dalam blended learning adalah kunci utama. 
JURNAL ILMU KESEHATAN BHAKTI HUSADA:

HeAlth SCIENCES Journal, Vol. 11 No. 02, DeSEMBER 2020

DOI: $10.34305 /$ jikbh.v11i2.205

Pembelajaran yang efektif dapat dipandang sebagai pembelajaran yang memanfaatkan teknologi informasi dan komunikasi sebagai alat bantu pembelajaran secara optimal (Alfi, 2017).

Aktivitas mahasiswa dalam upaya memperoleh informasi maupun kompetensi baru sesuai dengan capaian pembelajaran disebut dengan pengalaman belajar (Alfi, 2017). Menurut Sanjaya \& Wina (2008), menyatakan bahwa ada beberapa pertimbangan dalam menentukan pengalaman belajar, antara lain: pengalaman belajar sesuai dengan capaian pembelajaran yang telah dirumuskan, sesuai dengan jenis bahan atau materi siswa, ketersediaan sumber belajar, dan pengalaman belajar harus sesuai dengan karakteristik siswa. Pengalaman belajar lebih lama di klinik, menjadikan kelas non reguler mendapatkan nilai post test lebih tinggi dibanding kelas reguler. Beberapa literatur bahkan menyebutkan bahwa terdapat hubungan yang signifikan antara lama bekerja dengan kualitas pemberian asuhan serta pendokumentasian asuhan keperawatan. Artinya, bahwa pengalaman kerja dapat meningkatkan kemampuan penalaran masalah lebih unggul dibandingkan dengan
Ciptaan disebarluaskan di bawah

Lisensi Creative Commons

Atribusi-NonKomersial-

BerbagiSerupa 4.0 Internasional.

yang belum memiliki pengalaman langsung.

\section{Simpulan}

Blended learning preseptorshipdaring merupakan metode pembelajaran yang dapat diterapkan dalam proses pembelajaran mahasiswa program profesi Ners. Untuk capaian psikomotor dan afektif mahasiswa , perlu dipaparkan pada lingkungan nyata . nilai nilai profesionalisme sebagai profesi perawat akan sulit dicapai dengan menggunakan metode PBL ataupun online. Interaksi dengan perawat senior dan berbagai macam pasien akan memberikan pembelajaran yang nyata pada mahasiswa.

\section{Daftar Pustaka}

Alfi, C. (2017). Pengembangan Model Pembelajaran PBL Berbasis Blended Learning pada Mahasiswa PGSD UNU Blitar. Urnal Riset Dan Konseptual J, Volume 4 N.

Block, L. M., Claffey, C., Korow, M. K., \& Ruth. (2005). The Volue of Mentorship within Nursing Organization. Nursing Forum, Volume 40, .

CNA. (2004). Achieving Excellence. Author.

Erol, G., Yesin, S., \& Mahmet. (2008). Evaluation of problem based learning by tutors and student in a Medical Faculty of Turkey. Kuwait Medical Journal, Volume 40, 276-280. 
JURNAL ILMU KESEHATAN BHAKTI HUSADA:

HeAlth SCIENCES Journal, Vol. 11 No. 02, Desember 2020

DOI: $10.34305 /$ jikbh.v11i2.205

Ferguson. (2010). Nurse Education in Practice.

Jihad, A., \& Abdul, H. (2012). Evaluasi pembelajaran. Yogyakarta. Multi Pressindo.

Juniarti, N., Zannettino, L., Fuller, J., \& Grant, J. (2016). Defining service learning in nursing education: An integrative review. Jurnal Keperawatan Padjadjaran, Volume 4 N, 200-212.

Kushartanti. (2007). Pendekatan problembased learning dalam pembelajaran praktek kerja lapangan terapi fisik. Skripsi, Universita.

Nurhidayah, I. (2017). Perspektif Mahasiswa mengenai Problem-Based Learning (PBL). JKP, Volume $5 \mathrm{~N}$.

Omer. (2013). Perception of nursing students to two models of preceptorship in clinical training.

Rahmi, R., Rofiqul, U., Abdurrahman, \& Muhammad, S. (2019). The Effect of pliffed problem based learning, Model Integrated with LMS-Google Classroom for Senior Hight School Student. Journal for Education of Gifted Young Scientists, Volume 7 N, 137-158.

Sanjaya, \& Wina. (2008). rencanaan dan desain sistem pembelajaran. ncana Prenada Media Group.

Siahaan, S. (2003). E-Learning (Pembelajaran Elektroni) sebagai salah satu Alternatif Kegiatan Pembelajaran. Jurnal Pendidikan Dan Kebudayaan.
Ciptaan disebarluaskan di bawah

Lisensi Creative Commons

Atribusi-NonKomersial-

BerbagiSerupa 4.0 Internasional.

Staker, \& Horn. (2012). Classifying K-12 blended learning, iinosight institue.

Suhartanti, I. (2017). Metode Pembelajaran Klinik Berbasis Mentorship Terhadap Motivasi Dan Pencapaian Kompetensi Mahasiswa Dalam Praktik Klinik Keperawatan Medikal Bedah Di Rsud Sidoarjo. Thesis, Airlangga.

Sulung, \& neila. (2016). Efektivitas metode preseptor dan mentor dalam meningkatkan kompetensi perawat klinik. Jurnal Ipteks Terapan, VOLUME 9 NOMOR 2.

Suryani, \& Agung. (2017). dia Pembeljaarann Inovatif. PT Remaja Rosdakarya.

Tursina, A., Mujidin, \& Safaria, T. (2016). Pengaruh Bimbingan ... Kompetensi Klinik pada Mahasiswa. PSIKOPEDAGOGIA, Vol. 5, No.

Waryanto, N. H. (2006). online learning sebagai salah satu metode pembelajaran. Jurnal Pendidikan Matematika, Volume $2 n$. 